\title{
Clinical and laboratory findings of patients with Crimean-Congo hemorrhagic fever in the emergency department at hospital admission
}

\author{
İbak Gönen \\ University of Düzce, Faculty of Medicine, Department of Infectious Diseases, Düzce, Türkiye
}

\begin{abstract}
Objectives: The aim of this study was to evaluate clinical and laboratory features of CCHF cases on admission to the emergency department.
\end{abstract}

Materials and methods: Clinical and laboratory features of CCHF cases which applied to the emergency department of a district general hospital (Erbaa, Tokat Province) between the period of 2008 and 2010 were retrospectively assessed.

Results: Totally 15 cases were included in the study. Most of the patients applied with non-specific symptoms, some of them admitted with atypical symptoms such as abdominal pain and hematemesis. In three patients, all laboratory findings at admission were within normal limits.

Conclusions: Although, CCHF patients apply to hospital with nonspecific symptoms, some may have atypical symptoms like severe abdominal pain and hematemesis. Moreover, some may have normal leukocyte and platelet counts on admission. Therefore, for early diagnosis, physicians should have knowledge about the various clinical symptomatology of CCHF. J Microbiol Infect Dis 2011;1(1):1-4.

Key words: CCHF, emergency department, early diagnosis, clinical and laboratory findings

\section{Kırım-kongo kanamalı ateşi hastalarının acil servise başvuru esnasındaki klinik ve laboratuvar bulguları}

\section{ÖZET}

Amaç: Bu çalışmada Kırım-Kongo kanamalı ateşli (KKKA) olguların acil servise başvuru esnasındaki klinik ve laboratuar özelliklerinin değerlendirilmesi amaçlamıştır.

Gereç ve yöntem: 2008-2010 yıllarında görülen KKKA olgularının, bölgesel genel bir hastanenin (Erbaa, Tokat İli) acil servisine başvuru esnasındaki klinik ve laboratuar özellikleri retrospektif olarak değerlendirildi.

Bulgular: Çalışmaya toplam 15 olgu dahil edildi. Hastaların büyük kısmı nonspesifik bulgularla başvururken, bazı hastaların karın ağrısı, hematemez gibi atipik bulgularla başvurduğu görüldü. Üç olgunun başvuru esnasında laboratuar bulgularının normal sınırlarda olduğu tespit edildi.

Sonuçlar: KKKA hastaları nonspesifik belirtilerle başvurabileceği gibi, bazı hastalar şiddetli karın ağrısı, hematamez gibi atipik bulgularla başvurabilirler. Bunun yanında bazı hastaların başvuru esnasında lökosit ve trombosit sayıları normal sınırlarda olabilir. Bu nedenle hastalığın sık görüldüğü bölgelerde görev yapan hekimlerin hastalığın bu farklı klinik spektrumu açısından bilgilendirilmeleri, hastalığın erken tanısı açısından önemlidir.

Anahtar kelimeler: KKKA, acil servis, erken tanı, klinik ve laboratuar bulguları

\section{INTRODUCTION}

Crimean-Congo Hemorrhagic Fever (CCHF) is a severe viral infectious disease with a mean of $5 \%$ mortality rate, and characterized by fever and hemorrhages. The cause is a virus included in the Nairovirus group of the Bunyaviridae family. This virus is most commonly transmitted via tick bite. The disease can also be transmitted by contact with the infected tissues and fluids of sick animals or humans. Hyalomma spp. ticks, and particularly Hyalomma marginatum, are primarily involved in transmission of the viruses..$^{1-3} \mathrm{~A}$ regional outbreak has started in North, North-east and Central provinces of Turkey (Tokat, Sivas, Yozgat, Çorum, Amasya, Erzurum and Erzincan) 
in 2002. The disease was diagnosed as CCHF in $2003 .{ }^{4}$ New cases were reported from different cities and regions in subsequent years. Up to September 2010, 5317 cases and 267 deaths were reported. ${ }^{5}$

In the endemic area, any tick bite should be evaluated for CCHF. In some cases, there is not tick bite story on the admission. The disease consists of a one to nine-day incubation period followed by pre-hemorrhagic, hemorrhagic and improvement stages. The pre-hemorrhagic stage involves manifestations including fever, headache, fatigue, diffuse muscle and joint pain, abdominal pain, nausea, vomiting and diarrhea. Cases progressing to the hemorrhagic stage may have petechiae, ecchymosis, and hemorrhage of the gum, nose, internal organs and the gastrointestinal system. Cases recovering from the hemorrhagic stage enter the convalescent period 10 to 20 days after the onset of the disease. .,11-13 $^{13}$

In the endemic area, the Emergency Room physicians should be aware the suspected cases and their symptoms. This study was designed to evaluate the clinical and laboratory findings of $\mathrm{CCHF}$ cases at the time of presentation to the emergency room.

\section{MATERIALS AND METHODS}

This study was performed at Erbaa General Hospital between 2008 and 2010. Erbaa General Hospital is a 150-bed hospital providing an outpatient service to a mean of 1,500 patients daily, of who nearly 500 present to the emergency room. Erbaa County, located in the interior region of the Middle Blacksea Region exhibits the characteristics of the Black Sea climate. The district has a population of 95,815 . Sixty percent of the population lives in the district center. The majority of the population living in the villages is engaged in farming and stock breeding. While various numbers of cases had been reported in Tokat and its districts since 2002, the first cases of CCHF with definitive diagnosis occurred in 2008 in Erbaa.

In this study CCHF cases were evaluated retrospectively. At the admission, a specific chart was filled out for each suspected CCHF case. These charts were evaluated for this study. The cases were followed in the emergency room with the preliminary diagnosis of CCHF then hospitalized or referred with a potential diagnosis and diagnosed with CCHF at subsequent follow-ups. The following criteria were used to define the cases with CCHF.

\section{Description of certain case}

a) Case meeting the clinical description and confirmed by at least one laboratory criterion (demonstration of the virus RNA by Polymerase Chain Reaction (PCR) or demonstration of the virusspecific IGM antibodies) or

b) Case with an epidemiologic connection to a definite diagnosed case.

Based on these criteria, two of the 15 cases meeting the potential case description were monitored at our clinic while 13 were referred to a higher-level center. The definitive diagnosis was established through the Enzyme-linked immunosorbent assay (ELISA) and/or PCR tests performed on the blood samples sent to the Ministry of Health, Refik Saydam Hygiene Center Laboratory via the local health authority. The results of the patients were assessed during outpatient control visits. The study included those cases with diagnosis confirmed by laboratory results while those monitored with suspected CCHF without laboratory confirmation of the diagnosis were excluded from the study.

\section{RESULTS}

Between 2008 and 2010, 15 cases were diagnosed as CCHF. These 15 cases include ten males $(67 \%)$ and five females $(33 \%)$ with an age range of 10 to 81 and a mean age of $32.5 \pm 12.6$ years. Twelve of them $(80 \%)$ were living in rural area and 11 of them $(73 \%)$ were dealing with agriculture and animal husbandry jobs. All the cases presented in June, July and August. While ten patients $(67 \%)$ had a history of tick bite, five patients $(33 \%)$ had no history of tick contact. Three of the patients $(20 \%)$ detected to have tick contact, the ticks were detected by the emergency physician during the physical examination. The period from the detection of the tick to the onset of the disease was two to seven days (mean duration 5.4 days).

While 11 patients $(73 \%)$ had fever at the time of presentation, four had no complaint of fever. One patient $(6 \%)$ presented with hematemesis, and one patient $(6 \%)$ presented with abdominal pain. One patient $(6 \%)$ had markedly high AST 
and ALT levels as laboratory findings (Table 1). These patients were initially referred to the general surgeons and internists. All three patients $(20 \%)$ had normal laboratory findings at the time of initial presentation. The patients admitted for monitoring purposes, exhibited a dramatic deterioration of the laboratory findings on the investigations performed a day later. It was established that two patients with no history of tick bite were presenting to the emergency department with the complaint of fever for the third time. In these patients, who were administered treatment with the diagnosis of upper respiratory tract infection, and for whom no investigation was requested at the first two presentations, the platelet counts were below $10,000 / \mathrm{mm} 3$ at the time of the last presentation. Only one of the cases died due to CCHF. The mortality rate calculated as $7 \%$.

Table 1. The features of clinical and laboratory findings of $\mathrm{CCHF}$ cases at the admission.

\begin{tabular}{ll}
\hline Clinical and laboratory features & $\mathrm{n}(\%)$ \\
\hline Fatigue & $15(100)$ \\
Fever & $11(73)$ \\
Headache & $10(67)$ \\
Body pain & $10(67)$ \\
Nausea and vomiting & $6(40)$ \\
Abdominal pain & $6(40)$ \\
Diarrhea & $3(20)$ \\
Ecchymosis and petechiae & $3(20)$ \\
Thrombocytopenia & $12(80)$ \\
Leukopenia & $10(67)$ \\
Elevated aspartate transferase & $9(60)$ \\
Elevated alanine transferase & $9(60)$ \\
Elevated lactic dehydrogenase & $9(60)$ \\
Elevated creatine phosphokinase & $9(60)$ \\
Elevated prothrombin time & $6(40)$ \\
\hline
\end{tabular}

\section{DISCUSSION}

People engaged in farming and stock breeding represent the major risk group for $\mathrm{CCHF}^{3,}, 8,10,14$ In this study, $80 \%$ of the patients live in a rural area and $73 \%$ are engaged in farming and stockbreeding. Similar to the other studies, $80 \%$ of the cases were included in the 20-60 year-old group, who more actively participated in farming and stock-breeding. ${ }^{8}$ Only $55-60 \%$ of the patients with CCHF have a history of tick bite. ${ }^{7}$ In this study, $67 \%$ of the patients diagnosed with CCHF had a history of tick bite. Therefore, it would be beneficial to evaluate cases of fever with unexplained focus occurring in the summer months in endemic regions with respect to CCHF, even in the absence of a history of tick bite. In addition, patients presenting with the signs and symptoms of CCHF should be carefully examined physically with respect to the presence of ticks on the body. In this study, in three of the patients diagnosed with $\mathrm{CCHF}$, ticks were detected by the emergency physician during physical examination. CCHF cases exhibit climatic characteristics and a majority of the cases occur during the summer season when the ticks transmitting the virus become active and farm work increases. ${ }^{3}$ Similarly, all of the cases in this study were observed in June, July and August.

Complaints at the time of the first presentation in patients with CCHF are usually non-specific. As is the case in this study, fever, fatigue, nausea, vomiting, diarrhea and diffuse muscle pain and headache are the potential symptoms that may occur in this period. ${ }^{7,8}$; however, one should note that a portion of the patients may not have fever, particularly at the start of the disease. ${ }^{5}$ In this study, fever was not detected in $37 \%$ of the patients at the initial stage. Since the above symptoms determined at the initial stage may occur in the course of all viral infections, patients presenting with these symptoms during the summer months should be questioned for tick contact and journeys to rural regions, and in suspected cases, whole blood counts should be performed for investigating leucopenia and thrombocytopenia.

In CCHF, the most common laboratory findings include thrombocytopenia, leucopenia, and high LDH, CK and transaminase levels. ${ }^{8}$ However, one should note that the laboratory findings can be within the normal limits at the initial stage of the disease. In this study, all three patients with normal initial laboratory findings exhibited dramatic deteriorations in the investigations performed a day later. Therefore, patients at risk should be put under monitoring to repeat the investigations a day later if there are also clinical findings, even if the laboratory findings are normal. Some cases with CCHF may present with symptoms such as 
severe abdominal pain, nausea, vomiting and diarrhea. Such cases may occasionally be confused with acute abdominal syndrome. ${ }^{9}$ As is the case in a patient in this study, these patients may be referred to general surgeons. Due to these cases monitored without following the isolation measures, nosocomial transmissions may occur. ${ }^{10}$ Therefore, in endemic regions, the laboratory investigations of the patients presenting with complaints of fever and abdominal pain should be evaluated for CCHF. Similarly, there may be findings potentially observed in the course of various diseases such as hematemesis, melena or jaundice. ${ }^{7}$ As a matter of fact, a patient in this study presented to the hospital with the compliant of hematemesis. Patients presenting with these manifestations, who have blood disorders such as leucopenia and thrombocytopenia should be evaluated with respect to CCHF. CCHF may have various clinical manifestations. Physicians working in regions where the disease is common, report that some cases are confused with acute abdominal syndrome, some are monitored at internal disease clinics due to febrile neutropenia and gastrointestinal hemorrhage while some are hospitalized at gynecology clinics due to urogenital hemorrhage. While the initial symptoms of the disease are nonspecific, the clinical findings may be obscure in some cases, and in others, laboratory findings may not accompany the marked clinical manifestations at the start. In cases of unexplained fever occurring during the summer months, CCHF should be considered and the necessary assessments performed. In addition, patients with a history of tick bite should be monitored carefully for symptoms and findings, and suspected cases supported with laboratory findings. Such an approach would enable the diag- nosis of patients without delay, thereby ensuring early intervention and reducing nosocomial transmission.

\section{REFERENCES}

1. Peters CJ, California encephalitis, hantaa virus pulmonary syndrome, bunyavirid hemorrhagic fevers. In, Mandell GL, Bennet JE, Dolin R eds. Principles and practice of infectious diseases. 5th ed. New York Churchill Livingstone, 2000: 1849-1855.

2. Bodur H. Kırım-Kongo kanamalı Ateşi. In Symposium book of 'Istanbul Universitesi Cerrahpaşa Tıp Fakültesi Sürekli Tıp Eğitimi Etkinlikleri' No:55, 2007:267-277.

3. Ergonul O. Crimean-Congo Hemorrhagic Fever. Lancet Infect Dis 2006; 6:203-214.

4. Karti S, Odabaşı Z, Korten V, Yılmaz V, et al. Crimean Congo Hemorrhagic Fever in Turkey. Emerg Infect Dis 2004;10: 1379-1384.

5. Elaldı N. Klinik ve epidemiyolojik olarak KKKA hastalığında son durum. In; Symposium book of '3. Türkiye Zoonotik Enfeksiyonlar', Ankara 2010, 89-97.

6. Pelitli SM. Dünden bugüne KKKA. In; Symposium book of '3. Türkiye Zoonotik Enfeksiyonlar', Ankara 2010, 98-103.

7. Ergönül Ö. Türkiye'de ve Dünyada Kırım-Kongo kanamalı ateşi. In Congrees book of KLIMIK 2009, 127-137.

8. Cevik MA. Crimean-Congo Hemorrhagic Fever: Clinical Features. Klimik Derg 2004;17:59-61.

9. Celikbaş A, Ergönül O, Dokuzoğuz B, Eren S, Baykam N, Polat-Düzgün $A$. Crimean-Congo hemorrhagic infeciton simulating ace apendicitis. J Infect 2005;50:363-365.

10. Elaldı N. Epidemiolgy of Crimean Congo Hemorrhagic Fever. Klimik Derg 2004;17:151-156.

11. Bakır M, Ugurlu M, Dokuzoguz B, Bodur H, Taşyaran MA, Vahaboğlu H. Crimean-Congo hemorrhagic fever otbreak in Middle Anatolia: a multicentre study of clinical feautures and outcome measures. J Med Microbiol 2005;54:385-389.

12. Kara A. Crimean-Congo Hemorrhagic Fever. Türk Ped Arch 2008;43:108-118

13. Bakır M, Elaldı N. Crimean-Congo Hemorrhagic Fever. ANKEM Derg 2006;20:227-231.

14. Oztürk $D B$, Kuşçu $F$, Gürbüz $Y$, Gül $S$, Tütüncü $E D$, Şencan İ. Eveulation of $20 \mathrm{CCHF}$ cases during $2006-2007$ years. Klimik Derg 2008;21:93-96. 